\title{
PENERAPAN MODEL POLA KESEHATAN FUNGSIONAL GORDON TERHADAP TERIDENTIFIKASINYA MASALAH KEPERAWATAN KOMPREHENSIF PADA PASIEN DIABETES MELLITUS
}

\section{THE IMPLEMENTATION OF GORDON FUNCTIONAL HEALTH PATTERN ON THE IDENTIFICATION OF COMPREHENSIVE NURSING PROBLEMS IN DIABETES MELLITUS PATIENTS}

\author{
Puji Astuti Wiratmo ${ }^{1 *}$ Zakiyah $^{2}$, Sari Narulita ${ }^{3}$
}

\begin{abstract}
“1Universitas Binawan,Jl Dewi Sartika -Jl Kalibata Raya Jakarta Timur, email: puji@binawan.ac.id, Indonesia ${ }^{2}$ Universitas Binawan, JI Dewi Sartika-JI Kalibata Raya Jakarta Timur, email: zakiyah@binawan.ac.id, Indonesia

${ }^{3}$ Universitas Binawan,Jl Dewi Sartika-Jl Kalibata Raya Jakarta Timur, email: sari@binawan.ac.id, Indonesia
\end{abstract}

\begin{abstract}
Background: Patient with Diabetes ulcer / gangrene require a long period of treatment so that various nursing problems can arise including physical, psychological, social and spiritual problems related to the patient's response to the illness. Research conducted by Sofiana, et al (2012) of hospitalized patients with diabetic ulcers at Arifin Ahmad Hospital in Pekan Baru shows the results that more than $50 \%$ of patients experience psychosocial problems including low self-esteem, negative body image, negative self-concept, self-ideal irrelevant and high stress levels. Referring to the philosophy of nursing where nursing believes that humans and humanity are the central point of every health care effort and that human is a whole and unique creature of God Almighty that consist of bio-psycho-socio-spiritual and cultural aspects. Therefore, to be able to carry out their lives, human needs must be met in a balanced way that includes bio-psycho-sociospiritual and cultural.

Objective:The purpose of this study was to identify comprehensive nursing problems in nursing assessment by the Gordon Functional Health Pattern Model in Diabetic ulcer / gangrene patients.

Methods: This is a quantitative descriptive research with survey for the design. 20 Diabetic patient with ulkus or gangrene recruited as the sample though total sampling technique.

Results:Based on research conducted on 20 diabetic ulcer / gangrene patients in the medical nursing ward of Budi Asih Regional Hospital found that nursing problems in each of Gordon's functional health patterns can be identified.

Conclusion: .Nursing assessment with Gordon's pattern is able to identify the patient's nursing problems comprehensively in the biopsychososiospiritual aspects.
\end{abstract}

Keywords: , Comprehensive Nursing, Diabetes Mellitus, Gangren, Nursing Diagnosis

\section{LATAR BELAKANG}

Diabetes Melitus adalah penyakit yang ditandai dengan terjadinya hiperglikemia dan gangguan metabolism karbohidrat, lemak dan protein yang dihubungkan dengan kekurangan secara absolut atau relative dari kerja atau sekresi insulin. ${ }^{1}$ Penyakit yang ditimbulkan antara lain gangguan penglihatan mata, katarak, penyakit jantung, sakit ginjal, impotensi seksual, luka sulit sembuh dan membusuk/gangrene, infeksi paru-paru, gangguan pembuluh darah, stroke dan sebagaimya. $^{2}$

Berdasarkan informasi yang didapat dari International Diabetes Federation (IDF) disebutkan bahwa terdapat 415 juta orang menderita diabetes di dunia dan diperkirakan pada tahun 2040 penderita diabetes akan meningkat menjadi 642 juta orang. ${ }^{3}$ Jumlah 
orang dengan Diabetes Mellitus (DM) tipe 2 pada kelompok rentang usia antara 20 sampai 64 tahun juga akan meningkat di setiap negara. Di Indonesia populasi penderita DM mencapai 10 juta orang pada tahun 2015. Indonesia menempati urutan ketujuh sebagai negara dengan prevalensi DM terbanyak di dunia setelah Cina, India, USA, Brazil, Rusia dan Mexico.

Ulkus Diabetikum merupakan komplikasi yang paling ditakuti pasien Diabetes Mellitus karena berkurangnya suplay darah ke jaringan tersebut menyebabkan kematian jaringan dan diperparah dengan infeksi bakteri yang dapat menyebabkan amputasi bahkan berdampak luas karena dapat menyebabkan kematian, morbiditas, peningkatan biaya perawatan, dan penurunan kualitas hidup. Insiden ulkus kaki pada pasien Diabetes Mellitus yaitu 14\% dan 10-30 kali lipat Ulkus kaki menyebabkan risiko amputasi (ujung kaki, kaki maupun tungkai bawah). Diperkirakan setiap tahunnya satu juta pasien yang menderita Ulkus Diabetik menjalani amputasi ekstremitas bawah (85\%) dan angka kematian yaitu $15-40 \%$ setiap tahunnya serta $39-80 \%$ setiap 5 tahunnya. ${ }^{4}$ Prevalensi penderita ulkus gangrene di Indonesia sekitar $15 \%$, angka amputasi $30 \%$, angka mortalitas $32 \%$, dan ulkus diabetic merupakan sebab perawatan rumah sakit yang terbanyak sebesar $80 \%$ untuk diabetes mellitus. $^{5}$

Penyakit kaki diabetic berupa gangrene membutuhkan perawatan secara berkala dengan jangka waktu yang lama sehingga dapat menimbulkan permasalahanpermasalahan yang bersifat fisik, psikologis dan sosial yang dirasakan sebagai kondisi yang menekan. Masalah kesehatan yang berdampak pada kehilangan fungsi tubuh, penurunan toleransi aktivitas dan kesulitan dalam penanganan penyakit kronis seperti Ulkus Diabetikum inilah yang mengakibatkan terjadinya gangguan pada konsep diri individu khususnya harga diri rendah sehingga dapat menimbulkan perasaan bersalah atau menyalahkan, perilaku menyendiri, atau menghindar dari interaksi sosial yang akan berdampak pada proses penyembuhan bahkan memperparah prognosis. ${ }^{4}$ Hal ini juga ditunjukkan oleh penelitian yang dilakukan oleh Ningsih (2008) melalui wawancara dimana disimpulkan bahwa setiap pasien ulkus diabetes mengalami berbagai respon psikologis yang terindentifikasi dalam 4 tema yaitu menghadapi berbagai ketakutan, menjadi tidak berdaya, menjadi beban keluarga dan menyalahkan diri sendiri. ${ }^{6}$ Sedangkan dari respon sosial terdapat 2 tema yaitu menjadi tidak sebebas/tidak seaktif dulu dan menjadi tidak percaya diri dalam bergaul. Penelitian yang telah dilakukan oleh Sofiana, dkk (2012) terhadap pasien rawat inap dengan Ulkus Diabetik di RSUD Arifin Ahmad Pekan Baru menunjukkan hasil bahwa lebih dari $50 \%$ pasien mengalami permasalahan psikosial diantaranya harga diri rendah, citra tubuh 
negatif, konsep diri negatif, ideal diri tidak realistis dan tingkat stress tinggi. ${ }^{7}$

Berdasarkan kondisi tersebut dalam memberikan asuhan keperawatan perawat perlu memandang manusia sebagai mahluk yang holistic dimana intervensi keperawatan yang diberikan kepada pasien ulkus ganggren meliputi pemenuhan kebutuhan fisik, psikologis, social dan spiritual. Tujuan penelitian ini adalah untuk mengidentifikasi masalah keperawatan komprehensif melalui Model Pola Kesehatan Fungsional Gordon pada pasien Diabetes ulkus/gangrene.

\section{METODE PENELITIAN}

Rancangan penelitian ini adalah jenis deskriptif kuantitatif dengan desain penelitiannya adalah survey. Sebanyak 20 orang pasien Diabetes Ulkes/gangren yangdirawat di ruang rawat inap RSUD Budi Asih dengan dijadikan sampel dalam penelitian ini melalui teknik total sampling.

\section{HASIL DAN PEMBAHASAN}

Berdasarkan data demographic yang ada sebagian besar pasien (45\%) berada pada rentang usia lansia awal (46-55 tahun) dan yang lainnya dalah usia manula (>65 tahun) sebanyak $30 \%$, lalu usia lansia akhir (56-65 tahun) sebanyak 20\%. Adapun pasien dengan jenis kelamin perempuan lebih banyak (65\%) didapatkan dibanding dengan pasien laki-laki (35\%) dan berdasarkan status pernikahan hampir seluruh pasien (95\%) sudah menikah. Adapun latar belakang pendidikan pasien sebagian besar masih berada pada tingkat pendidikan dasar yaitu $55 \%$ pada tingkat pendidika SD dan SMP, hasil seperti tabel 1 dibawah ini.

Tabel 1. Distribusi Karakteristik Responden berdasarakan umur, jenis kelamin, pendidikan, pekerjaan, status pernikahan, pendidikan, pekerjaan, agama dan suku

\begin{tabular}{|c|c|c|c|}
\hline No & Varibel & Frek & $(\%)$ \\
\hline \multirow[t]{6}{*}{1} & Umur & & \\
\hline & $\begin{array}{l}\text { Dewasa Awal (26-35 } \\
\text { Tahun) }\end{array}$ & 0 & 0 \\
\hline & $\begin{array}{l}\text { Dewasa Akhir (36-45 } \\
\text { Tahun) }\end{array}$ & 1 & 5 \\
\hline & $\begin{array}{l}\text { Lansia Awal (46-55 } \\
\text { Tahun) }\end{array}$ & 9 & 45 \\
\hline & $\begin{array}{l}\text { Lansia Akhir (56-65 } \\
\text { Tahun) }\end{array}$ & 4 & 20 \\
\hline & Manula (>65 Tahun) & 6 & 30 \\
\hline \multirow[t]{3}{*}{2} & Jenis Kelamin & & \\
\hline & Laki-Laki & 7 & 35 \\
\hline & Perempuan & 13 & 65 \\
\hline \multirow[t]{3}{*}{3} & Status Pernikahan & & \\
\hline & Menikah & 19 & 95 \\
\hline & Tidak Menikah & 1 & 5 \\
\hline \multirow[t]{5}{*}{4} & Pendidikan & & \\
\hline & SD & 4 & 20 \\
\hline & SMP & 7 & 35 \\
\hline & SMA & 5 & 25 \\
\hline & PT & 0 & 0 \\
\hline \multirow[t]{9}{*}{5} & Pekerjaan & & \\
\hline & Petani & 0 & 0 \\
\hline & Wiraswasta & 7 & 35 \\
\hline & Pegawai Swasta & 0 & 0 \\
\hline & PNS/TNI/POLRI & 0 & 0 \\
\hline & $\begin{array}{l}\text { Pensiunan } \\
\text { PNS/TNI/POLRI }\end{array}$ & 1 & 5 \\
\hline & Ibu Rumah Tangga & 10 & 50 \\
\hline & Pekerja Lepas & 2 & 10 \\
\hline & Tidak Bekerja & 0 & 0 \\
\hline \multirow[t]{6}{*}{6} & Agama & & \\
\hline & Islam & 19 & 95 \\
\hline & Kristen Protestan & 1 & 5 \\
\hline & Kristen Katolik & 0 & 0 \\
\hline & Buddha & 0 & 0 \\
\hline & Hindu & 0 & 0 \\
\hline \multirow[t]{3}{*}{7} & Suku & & \\
\hline & Batak & 2 & 10 \\
\hline & Jawa & 12 & 60 \\
\hline
\end{tabular}


Berdasarkan data demographic yang ada sebagian besar pasien (45\%) berada pada rentang usia lansia awal (46-55 tahun) dan yang lainnya dalah usia manula (>65 tahun) sebanyak $30 \%$, lalu usia lansia akhir (56-65 tahun) sebanyak 20\%. Adapun pasien dengan jenis kelamin perempuan lebih banyak $(65 \%)$ didapatkan dibanding dengan pasien laki-laki (35\%) dan berdasarkan status pernikahan hampir seluruh pasien (95\%) sudah menikah. Adapun latar belakang pendidikan pasien sebagian besar masih berada pada tingkat pendidikan dasar yaitu $55 \%$ pada tingkat pendidikan SD dan SMP, hanya $25 \%$ yang SMA dan tidak ada yang di perguruan tinggi. Pekerjaan responden terbanyak adalah ibu rumah tangga (50\%) dan yang lainnya adalah wiraswasta (35\%) dan pekerja lepas $10 \%$.Suku terbanyak pada responden adalah suku jawa (60\%).

Hasil penelitian menunjukkan rerata usia responden berada pada usia lansia. Usia diatas 45 tahun merupakan faktor risiko terhadap peningkatan jumlah pasien DM, selain faktor riwayat keluarga dan juga obesitas. Proses penuaan yang disebabkan oleh perubahan anatomis, fisiologis dan biokimia menyebabkan penurunan sensitivitas insulin dan terjadinya gangguan sel beta yang menyebabkan produksi insulin berkurang biasanya terjadi pada usia lanjut. Proses bertambah usia dapat mempengaruhi proses homestatsi tubuh, termasuk perubahan fungsi sel beta pancreas yang menghasilkan insulin yang akan menyebabkan gangguan sekresi hormone atau penggunaan glukosa yang tidak adekuat pada tingkat sel yang berdampak terhadap peningkatan glukosa dalam darah. Pada usia 50 tahun ke atas akan terjadi peningkatan 5$10 \mathrm{mg} / \mathrm{dL}$ per tahun. ${ }^{8}$ Jumlah pasien perempuan yang menderita DM lebih banyak dibandingkan dengan yang laki-laki, hal tersebut dikarenakan faktor risiko kegemukan dimana perempuan mempunyai hormone estrogen yang menyebabkan peningkatan jumlah endapan lemak didalam jaringan sub kutis. Pada perempuan jumlah lemak lebih dari $35 \%$ sedangkan pada laki-laki jumlah lemak lebih dari $25 \%{ }^{8}$

Tabel 2. Distribusi diagnose keperawatan responden berdasarkan pola persepsi dan manajemen kesehatan

\begin{tabular}{|c|c|c|}
\hline $\begin{array}{c}\text { Diagnosa } \\
\text { Keperawatan }\end{array}$ & Frekuensi & $\begin{array}{c}\text { Presentase } \\
(\%)\end{array}$ \\
\hline Risiko infeksi & 12 & $60 \%$ \\
\hline $\begin{array}{l}\text { Potensi } \\
\text { komplikasi : } \\
\text { sepsis }\end{array}$ & 7 & $35 \%$ \\
\hline $\begin{array}{l}\text { Ketidakefektifan } \\
\text { pemeliharaan } \\
\text { kesehatan }\end{array}$ & 10 & $50 \%$ \\
\hline $\begin{array}{l}\text { Ketidakefektifan } \\
\text { manajemen } \\
\text { kesehatan diri }\end{array}$ & 2 & $10 \%$ \\
\hline Ketidakpatuhan & 2 & $10 \%$ \\
\hline $\begin{array}{l}\text { Resiko respon } \\
\text { alergi }\end{array}$ & 1 & $5 \%$ \\
\hline
\end{tabular}

Pada tabel 2 masalah keperawatan pada pola Persepsi dan Majanemen Kesehatan ditemukan 3 masalah terbanyak yaitu Risiko infeksi sebanyak 12 orang (60\%), Ketidakefektifan pemeliharaan kesehatan sebanyak 10 orang (50\%),dan potensial komplikasi sepsis sebanyak 7 orang (35\%). 
Risiko infeksi adalah suatu kondisi yang berisiko terhadap invasi organisme pathogen gangrene. ${ }^{9}$ Penyakit kronis seperti DM merupakan salah satu faktor risiko yang dapat menyebabkan infeksi, ditambah lagi dengan adanya kerusakan integritas kulit dan menurunnya perfusi jaringan perifer pada luka ulkus atau gangrene. Infeksi pada pasien DM sangat berpengaruh terhadap pengendalian glukosa darah. Infeksi dapat memperburuk kendali glukosa darah, dan kadar glukosa darah yang tinggi meningkatkan kerentanan dan memperburuk infeksi. ${ }^{1}$ Glukosa darah yang tinggi pada pasien DM menggangu fungsi kekebalan tubuh dalam menghadapi masuknya virus atau kuman sehingga penderita diabetes mudah terkena infeksi. Kadar glukosa darah yang tinggi juga merusak sistem saraf sehingga mengurangi kepekaan penderita terhadap adanya infeksi .

Masalah keperawatan selanjutnya adalah Ketidakefektifan pemeliharaan kesehatan yaitu ketidakmampuan untuk mengidentifikasi, menatalaksana atau mencari bantuan untuk memelihara kesehatan.Batasan karakteristik pada diagnosa ini ditandai dengan kurang minatnya pasien dalam meningkatkan perilaku sehat, serta menunjukkan kurang pengetahuan tentang praktik dasar kesehatan. Hasil penelitian terkait menunjukkan perilaku perawatan diri DM berdasarkan aspek pemantauan kadar gula darah sebanyak $44,4 \%$ responden masih kurang melakukan pemantauan gula darah, perilaku minum obat DM kurang baik sebanyak $20 \%$, latihan fisik kurang baik $43 \%$, dan perilaku pola makan diet kurang baik sebanyak $48,9 \%{ }^{10}$ Hasil ini menunjukkan kurangnya kemampuan pasien dalam melakukan manajemen kesehatan diri.DM merupakan penyakit metabolic kronis yang tidak dapat disembuhkan dan akan menyertai penderita seumur hidup sehingga mempengaruhi kualitas hidupnya. Maka pengelolaan kualitas hidup yang baik dapat mengendalikan perjalanan penyakit DM.

Sebaliknya, pengontrolan kualitas hidup yang tidak baik seperti yang terindentifikasi pada hasil penelitian ini berupa tidak rajin mengontrol gula darah akan menyebabkan komplikasi DM. ${ }^{11}$ Menanggapi permasalahan tersebut maka peran penting perawat sebagai bagian dari tim kesehatan dalam manajemen DM meliputi promosi kesehatan, pencegahan penyakit, pelayanan pasien dan menyederhanakan kepatuhan pasien. ${ }^{12}$

Berdasarkan tabel 3 dibawah ini pada pola nutrisi metabolik ditemukan tiga masalah utama yaitu Resiko ketidakstabilan gula darah(100\%), Gangguaan pemenuhan nutrisi kurang dari kebutuhan, dan Gangguan integritas kulit/jaringan (100\%). Sedangkan masalah terbesar lainnya adalah Ketidakseimbangan nutrisi kurang dari kebutuhan tubuh sebanyak 14 orang (23\%). 
Tabel 3. Distribusi diagnose keperawatan responden berdasarkan Pola Nutrisi Metabolik

\begin{tabular}{lcc}
\hline \multicolumn{1}{c}{$\begin{array}{c}\text { Diagnosa } \\
\text { Keperawatan }\end{array}$} & Frekuensi & $\begin{array}{c}\text { Presentase } \\
\text { (\%) }\end{array}$ \\
\hline $\begin{array}{l}\text { Resiko } \\
\text { ketidakstabilan } \\
\text { glukosa darah }\end{array}$ & 20 & $100 \%$ \\
\hline $\begin{array}{l}\text { Ketidakseimbangan } \\
\text { Nutrisi kurang dari } \\
\text { kebutuhan tubuh } \\
\text { /Resiko }\end{array}$ & 14 & $23 \%$ \\
\hline $\begin{array}{l}\text { Resiko kekurangan } \\
\text { volume cairan }\end{array}$ & 1 & $5 \%$ \\
\hline Hipertermia & 1 & $5 \%$ \\
\hline $\begin{array}{l}\text { Ketidakseimbangan } \\
\text { Nutrisi : lebih dari } \\
\text { kebutuhan tubuh }\end{array}$ & 1 & $5 \%$ \\
\hline $\begin{array}{l}\text { Kerusakan integritas } \\
\text { kulit }\end{array}$ & 20 & $100 \%$ \\
\hline $\begin{array}{l}\text { Potensial komplikasi: } \\
\text { Nefropati }\end{array}$ & 1 & $5 \%$ \\
\hline Sumber : Data Primer 2019 & & \\
\hline
\end{tabular}

Risiko ketidakstabilan glukosa darah adalah resiko terjadinya variasi kadar glukosa/gula darah dari rentang normal yang dapat mengganggu kesehatan. ${ }^{9}$ Mekanisme resistensi insulin yang terjadi pada DM tipe 2 dapat mengakibatkan meningkatnya kadar gula di dalam darah(hiperglikemia). Faktor resiko yang teridentifikasi pada responden berdasarkan hasil penelitian antara lain pemantauan glukosa darah yang tidak adekuat, kurangnya penatalaksanaan tindakan diabetes serta status kesehatan fisik.

Terjadinya hiperglikemia dikaitkan dengan adanya omnious octet pada tubuh penderita diantaranya: kegagalan sel beta untuk memproduksi insulin dalam upaya mengkompensasi peningkatan resistensi insulin, peningkatan produksi glukosa pada hepar karena resistensi insulin, gangguan utilisasi dan transportasi glukosa pada otot, peningkatan pemecahan pada sel lemak (lipolysis), terjadinya defisiensi GLP-1 pada usus dan berkurangnya increatin effect, peningkatan sinteis glucagon pada dari sel alpha pancreas padaorang ynag berpuasa, peningkatan reabsorsi glukosa pada ginjal, dan resistensi insulin pada sel otak. ${ }^{13}$

Ketidakseimbangan Nutrisi kurang dari kebutuhan tubuh/Resiko merupakan asupan nutrisi tidak mencukupi kebutuhan metabolik. Batasan karakteristik yang ditemukan pada responden antar lain terdapatnya pasien dengan berat badan kurang dari $20 \%$ dari berat badan ideal atau berdasarkan penghitungan Indeks Masa Tubuh pada kategori kurang, hipoalbuminemia pada beberapa orang responden dan data subjektif asupan makanan yang tidak adekuat karena penurunan nafsu makan, mual dan muntah. Gangguan saluran cerna pada penderita diabetes disebabkan karena kontrol glukosa darah yang tidak baik, serta gangguan saraf otonom yang mengenai saluran pencernaan. Rasa sebah, mual, bahkan muntah dan diare juga bisa terjadi. Ini adalah akibat dari gangguan saraf otonom pada lambung dan usus. Keluhan gangguan saluran makan bisa juga timbul akibat pemakaian obat-obatan yang diminum. ${ }^{1}$

Kerusakan integritas kulit merupakan perubahan yang terjadi pada epidermis dan dermis, seperti halnya pada beberapa responden yang mengalami ulkus DM. Sedangkan kerusakan yang terjadi lebih 
dalam dari epidermis maka diagnose keperawatan yang tertulis adalah Kerusakan intergritas jaringan seperti yang teridentifkasi pada beberapa orang pasien yang mengalami gangrene dan ulkus yang lebih dalam. Seluruh responden teridentifikasi terhadap diagnose keperawatan ini. Faktor yang berperan dalam pathogenesis ulkus DM dan gangrene meliputi hiperglikemia kronik, neuropati perifer, keterbatasan sendi dan deformitas. Sistem saraf dirusak dengan keadaan hiperglikemia dan juga penurunan kadar oksigen jaringan akibat gangguan aliran darah pembuluh tungkai yang merupakan manifestasi dari penyakit arteri perifer. Penyakit arteri perifer padapembuluh darah tungkai didasari oleh hiperglikemia kronik, kerusakan endotel dan terbentuknya plak aterosklerosis. ${ }^{14}$

Tabel 4. Distribusi diagnose keperawatan responden berdasarkan pola eliminasi

\begin{tabular}{lcc}
\hline \multicolumn{1}{c}{$\begin{array}{c}\text { Diagnosa } \\
\text { Keperawatan }\end{array}$} & Frekuensi & $\begin{array}{c}\text { Persentase } \\
(\%)\end{array}$ \\
\hline $\begin{array}{l}\text { Gangguan } \\
\text { eliminsai urin: } \\
\text { poliuri }\end{array}$ & 6 & $30 \%$ \\
\hline $\begin{array}{l}\text { Gangguan } \\
\text { eliminasi fekal: } \\
\text { konstipasi }\end{array}$ & 1 & $5 \%$ \\
\hline Sumber : Data Primer 2019 & &
\end{tabular}

Berdasarkan tabel 4 ada dua masalah keperawatan yangteridentifikasi pada responden yaitu gangguan eliminasi urin: poliuri sebanyak 6 orang $(30 \%)$ dan gangguan eliminasi fekal sebanyak 1 orang $(5 \%)$.
Tabel 5. Distribusi diagnose keperawatan respondenberdasarkan Pola Aktifitas dan Latihan

\begin{tabular}{lcc}
\hline \multicolumn{1}{c}{$\begin{array}{c}\text { Diagnosa } \\
\text { Keperawatan }\end{array}$} & Frekuensi & $\begin{array}{c}\text { Persentase } \\
(\%)\end{array}$ \\
\hline Intoleran aktifitas & 7 & $35 \%$ \\
\hline $\begin{array}{l}\text { Hambatan } \\
\text { mobilitas fisik }\end{array}$ & 10 & $50 \%$ \\
\hline $\begin{array}{l}\text { Disfungsi } \\
\text { neurovascular } \\
\text { perifer }\end{array}$ & 2 & 10 \\
\hline $\begin{array}{l}\text { Defisit perawatan } \\
\text { diri: mandi dan } \\
\text { hygiene }\end{array}$ & 2 & $2 \%$ \\
\hline $\begin{array}{l}\text { Ketidakefetifan } \\
\text { perfusi jaringan } \\
\text { perifer/Resiko }\end{array}$ & 20 & 100 \\
$\begin{array}{l}\text { Sumber : Data Primer } 2019 \\
\end{array}$ &
\end{tabular}

Berdasarkan tabel 5 masalah keperawatan terbanyak yang teridentifikasi pada responden antara lain Ketidakefektifan perfusi jaringan perifer sebanyak 20 orang $(100 \%)$, hambatan mobilitas fisik sebanyak 10 orang $(50 \%)$, dan intoleransi aktifitas sebanyak 7 orang (35\%).

\section{Tabel 6. Distribusi diagnose keperawatan responden berdasarkan Pola Kognitif Persepsi}

\begin{tabular}{lcc}
\hline \multicolumn{1}{c}{$\begin{array}{c}\text { Diagnosa } \\
\text { Keperawatan }\end{array}$} & Frekuensi & $\begin{array}{c}\text { Persentase } \\
\text { (\%) }\end{array}$ \\
\hline Nyeri akut & 14 & $70 \%$ \\
\hline $\begin{array}{l}\text { Kurang } \\
\text { pengetahuan: } \\
\text { proses penyakit } \\
\text { dan komplikasi } \\
\text { penyakit }\end{array}$ & 13 & \\
\hline Sumber : Data Primer 2019 & & \\
\end{tabular}

Berdasarkan tabel 6 masalah keperawatan yang teridentifikasi pada responden antara lain Nyeri akut sebanyak 14 orang (70\%) dan Kurang pengetahuan sebanyak 13 orang (65\%). Kurang pengetahuan tentangproses penyakit dan komplikasi penyakit adalah ketiadaan atau kurangnya informasi kognitif yang berkaitan dengan topik tertentu dalam 
hal ini mekanisme/proses penyakit DM serta komplikasinya. Sebanyak 13 orang pasien menyatakan ketidaktahuan terhadap penyakitnya serta bahaya komplikasi yang dapat ditimbulkan serta menunjukkan persepsi yang salah terhadap masalah kesehatan yang dialaminya menunjukkan perilaku yang tidak sesuai dengan anjuran. ${ }^{15}$

Tabel 7. Distribusi diagnose keperawatanrespondenberdasarkan Pola Persepsi Konsep Diri

\begin{tabular}{lcc}
\hline \multicolumn{1}{c}{$\begin{array}{c}\text { Diagnosa } \\
\text { Keperawatan }\end{array}$} & Frekuensi & $\begin{array}{c}\text { Presentase } \\
\mathbf{( \% )}\end{array}$ \\
\hline Ansietas & 10 & $50 \%$ \\
\hline Keputusasaan & 1 & $5 \%$ \\
\hline Ketidakberdayaan & 2 & $10 \%$ \\
\hline $\begin{array}{l}\text { Harga diri rendah } \\
\text { situasional }\end{array}$ & 2 & $10 \%$ \\
\hline $\begin{array}{l}\text { Sumber : Data Primer 2019 } \\
\text { Berdasarkan tabel }\end{array}$ & sebanyak & 10 orang
\end{tabular}
responden mengalami Ansietas (50\%), diikuti dengan Ketidakberdayaan dan Harga Diri Rendah Situasional masing-masing sebanyak 2 orang (10\%) dan Keputusasaan sebanyak 1 orang (5\%).

Ansietas adalah perasaan tidak nyaman atau kekhawatiran yang samar disertai respons otonom (sumber seringkali tidak spesifik atau tidak diketahui oleh individu) yang disebabkan oleh antisipasi terhadap bahaya.Berdasarkan hasil penelitian sebanyak 10 orang $(10 \%)$ responden mengalami ansitas tingkat sedang dimana lapang persepsi pasien menyempit, berfokus pada pada perhatian segera, dan tidak terlalu memperhatikan komunikasi dan detil yang lain. Batasan karakteristik yang ditemukan pada pasien antara lain mengekspresikan perasaan kekhawatiran terhadap kondisi penyakitnya, perasaan takut tidak bisa sembuh, takut kakinya akan diamputasi, ketidakpastian akan hidupnya dengan sakit yang dialaminya dan terlihat ketegangan wajah pada pasien.

Keputusasaan merupakan kondisi subjektif ketika individu melihat keterbatasan atau ketiadaan alternatif atau pilihan pribadi yang tersedia dan tidak dapat memobilisasi energy untuk kepentingan individu. Satu orang pasien menyatakan merasa putus asa karena penyakitnya tak kunjung sembuh dan ia beranggapan penyakitnya tidak akan pernah sembuh walaupun ia melakukan pemeriksaan kesehatan. la khawatir luka dikakinya akan bertambah parah dan berdampak tidak baik seperti yang terjadi pada jempol kirinya.

Ketidakberdayaan adalah merasa kehilangan kendali terhadap situasi termasuk persepsi bahwa tindakan individu tidak akan mempengaruhi hasil secara bermakna. Sebanyak 2 orang (10\%) pasien mengalami Ketidakberdayaan dengan ditemukannya data bahwa mereka menyatakan merasa tidak berdaya dan tidak bisa melakukan aktiftas dengan sakitnya, frustasi terhadap ketidakmampuan untuk melakukan aktifitas sebelumnya, menyatakan keraguan tentang performa peran. Penelitian yang dilakukan terkait pada pasien dengan ulkus DM juga teridentifikasi adanya masalah keputusasaan dan ketidakberdayaan pada responden. ${ }^{6}$

Harga diri rendah situasional merupakan terjadinya perkembangan 
persepsi negatif tentang harga diri sebagai respon terhadap situasi saat ini (sakit kronis DM dan luka kronis ulkus atau gangrene). Masalah kesehatan yang berdampak pada kehilangan fungsi tubuh, penurunan toleransi aktivitas dan kesulitan dalam penanganan penyakit kronis seperti Ulkus Diabetikum inilah yang mengakibatkan terjadinya gangguan pada konsep diri individu khususnya harga diri sehingga dapat menimbulkan perasaan bersalah atau menyalahkan, perilaku menyendiri, atau menghindar dari interaksi sosial yang akan berdampak pada proses penyembuhan bahkan memperparah prognosis. ${ }^{4}$ Penelitian lainnya yang dilakukan pada pasien DM di RSUD Pekan Baru ditemukan sebanyak 66,7 $\%$ pasien mengalami harga diri rendah. ${ }^{7}$

Tabel 8. Distribusi diagnose keperawatan responden berdasarkan Pola Tidur dan Istirahat

\begin{tabular}{lcc}
\hline $\begin{array}{c}\text { Diagnosa } \\
\text { Keperawatan }\end{array}$ & Frekuensi & $\begin{array}{c}\text { Presentase } \\
\text { (\%) }\end{array}$ \\
\hline $\begin{array}{l}\text { Gangguan pola } \\
\text { tidur }\end{array}$ & 7 & $35 \%$ \\
\hline Sumber : Data Primer 2019 & &
\end{tabular}

Berdasarkan tabel 8 didapatkan sebanyak 7 orang pasien (35\%) mengalami Gangguan pola tidur.

Tabel 9. Distribusi diagnose keperawatan respondenberdasarkan Pola Peran Hubungan

\begin{tabular}{lcc}
\hline $\begin{array}{l}\text { Diagnosa } \\
\text { Keperawatan }\end{array}$ & Frekuensi & $\begin{array}{l}\text { Presentase } \\
(\%)\end{array}$ \\
\hline $\begin{array}{l}\text { Ketidakefektifan } \\
\text { penampilan peran }\end{array}$ & 9 & $45 \%$ \\
\hline Resiko kesepian & 1 & $5 \%$ \\
\hline Sumber : Data Primer 2019 & &
\end{tabular}

Berdasarkan tabel 9 sebanyak 9 orang responden (45\%) mengalami masalah keperawatan Ketidakefektifan penampilan peran dan satu orang (5\%) mengalami Resiko kesepian.

Ketidakefektifan penampilan peran merupakan gambaran pola dan perilaku ekspresi diri yang tidak sesuai dengan konteks lingkungan, norma dan harapan. Sebanyak 9 orang pasien (45\%) mengalami masalah keperawatan tersebut dengan batasan karakteristik yang ditemukan adanya pelaporan bahwa pasien berhenti bekerja karena penyakitnya, ketidaktentuan penghasilan yang didapatkan karena sakitnya, perubahan pola tanggung jawab yang biasanya, serta perubahan dalam kapasitas untuk melalukan kembali peran.

Tabel 10. Distribusi diagnose keperawatan responden berdasarkan Pola Seksual Reproduksi

\begin{tabular}{ccc}
\hline $\begin{array}{c}\text { Diagnosa } \\
\text { Keperawatan }\end{array}$ & Frekuensi & $\begin{array}{c}\text { Presentase } \\
\mathbf{( \% )}\end{array}$ \\
\hline Disfungsi seksual & 1 & $5 \%$ \\
\hline Sumber : Data Primer 2019 & &
\end{tabular}

Berdasarkan table 10 sebanyak 1 orang $(5 \%)$ pasien mengalami masalah keperawatan Disfungsi seksual.Disfungsi seksual, dimana ini adalah kondisi ketika individu mengalami perubahan fungsi seksual selama fase respons gairah seksual, rangsang seksual, dan/atau orgasme, yang dipandang tidak memuaskan, tidak ada penghargaan, atau tidak adekuat.Data yang didapatkan dari hasil pengkajian yaitu saat sakit klien lebih merasa bahwa kebutuhan seksualnya tidak terpenuhi dan sangat terganggu karena sulit untuk mencapai orgasme ejakulasi yang membuatnya menjadi kesal pada diri sendiri dan merasa 
tidak mampu memenuhi kebutuhan seksual dirinya dan istrinya. Disfungsi seksual merupakan komplikasi akibat DM, hal tersebut mencakup penurunan libido, masalah ejakulasi dan disfungsi ereksi yang mengakibatkan impotensi.DM dapat merusak pembuluh darah dan saraf yang mengontrol ereksi baik saraf sensorik, motorik dan saraf otonom.Kenaikan gula darah menyebabkan terjadinya penyempitan pembuluh darah pada alat kelamin laki-laki, sehingga aliran darah menjadi tidak lancar.Hiperglikemia juga menyebabkan zat nitrat oksida (zat yang dapat meningkatkan ereksi alat kelamin lakilaki) tidak bisa dihasilkan dalam jumlah banyak, bahkan merusak zat tersebut dan akhirnya sinyal untuk ereksi tidak bisa disampaikan ke otak. ${ }^{16}$

Tabel 11. Distribusi diagnose keperawatan responden berdasarkan Pola Toleransi Stress Koping

\begin{tabular}{lcc}
\hline \multicolumn{1}{c}{$\begin{array}{c}\text { Diagnosa } \\
\text { Keperawatan }\end{array}$} & Frekuensi & $\begin{array}{c}\text { Presentase } \\
(\%)\end{array}$ \\
\hline $\begin{array}{l}\text { Koping individu } \\
\text { tidak efektif }\end{array}$ & 1 & $5 \%$ \\
\hline Sumber : Data Primer 2019 & &
\end{tabular}

Berdasarkan tabel 11 diidentifikasi satu orang (5\%) mengalami masalah Koping individu tidak efektif.

Tabel 12. Distribusi diagnose keperawatan responden berdasarkan Pola Nilai dan Kepercayaan

\begin{tabular}{lcc}
\hline $\begin{array}{l}\text { Diagnosa } \\
\text { Keperawatan }\end{array}$ & Frekuensi & $\begin{array}{l}\text { Presentase } \\
(\%)\end{array}$ \\
\hline $\begin{array}{l}\text { Hambatan } \\
\text { religiolitas }\end{array}$ & 17 & $85 \%$ \\
\hline Distress spiritual & 2 & $10 \%$ \\
\hline Sumber : Data Primer 2019 & &
\end{tabular}

Berdasarkan tabel 12. didapatkan sebanyak 17 orang (85\%) mengalami masalah
Hambatan religiolitas dan sebanyak 2 orang $(10 \%)$ mengalami Disstress spiritual.

Hambatan religiolitas merupakan hambatan kemampuan untuk melatih keyakinan beragama dan/atau berpartisipasi dalam ritual tradisi kepercayaan tertentu. Sebanyak 17 responden (85\%) mengalami masalah ini dengan batasan karakteristik yang ditemukan pada responden antar lain kesulitan untuk mematuhi anjuran keyakinan keagamaan pada pasien muslim yang tidak menjalankan ibadah sholat selama mereka dirawat dirumah sakit disebabkan oleh kelemahan fisik, kurangnya kemauan dan kurang pengetahuan terhadap tata cara wudhu dan sholat ditempat tidur.

Distress spiritual adalah hambatan kemampuan untuk mengalami dan mengintegrasikan makna dan tujuan dalam hidup melalui hubungan dengan diri sendiri, orang lain, musik, seni, buku, alam, ataupun dengan Tuhan Yang Maha Esa.Sebanyak 2 pasien $(10 \%)$ mengalami masalah ini dengan batasan karakteristik yang ditemukan rasa kekhawatiran pasien yang tidak bisa sembuh dari penyakitnya yang sudah berlangsung lama dan pasien merasakan sakitnya sebagai hukuman dari Tuhan.Pasien juga mengatakan merasa cemas dengan kondisi sakitnya, merasa hidup kurang bergairah dan tidak bersemangat menjalani pengobatan.

\section{KESIMPULAN}

Berdasarkan hasil penelitian yang dilakukan pada pasien DM ulkus/gangrene disimpulkan 
bahwa melalui pengkajian pola Gordon dapat teridentifikasi masalah keperawatan komprehensif di setiap pola kesehatan fungsional responden.

Hasil penelitian ini dapat menjadi rujukan bagi perawat dalam melakukan pengkajian secara komprehensif dengan menggunakan pola Gordon sehingga asuhan keperawatan yang diberikan pada pasien dapat memenuhi kebutuhan aspek biopsikososiospiritual pasien. Beberapa permasalahan keperawatan yang teridentifikasi dari hasil penelitian ini dapat ditindaklanjuti oleh perawat untuk mengembangkan standar asuhan keperawatan komprehensif sesuai dengan kapasitas rumah sakit agar dapat meningkatkan kualitas asuhan keperawatan. Berdasarkan hasil penelitian ini diharapkan bagi perawat yang memberikan asuhan keperawatan pada penderita DM tipe 2 agar mempertimbangkan aspek psikososiospiritual pasien karena tingkat stress yang berat tidak hanya dapat mengubah konsep diri pasien menjadi negatif tetapi juga dapat memperparah penyakit pasien. Penelitian lanjutan terkait dengan asuhan keperawatan komprehensif dapat dilakukan terutama penelitian yang mendalam terhadap kebutuhan psikososial pasien melalui penelitian kualitatif ataupun penelitian terhadap analisa kemampuan perawat dalam memenuhi kebutuhan psikososiospiritual pasien.

\section{TERIMA KASIH}

1. Kemenristekdikti dan LLDIKTI 3

2. Dr.M.Sofyan Hawadi,MA Rekotor Universitas Binawan, email: pmb@binawan.ac.id

3. Maryuni,SKM,MKM, Ketua LPPM Universitas Binawan, email: Ippm@binawan.ac.id

\section{KEPUSTAKAAN}

1. Soelistijo $S$, Novida $H$, Rudijanto $A$, Soewondo P, Suastika K, Manaf A, et al. Konsesus Pengelolaan Dan Pencegahan Diabetes Melitus Tipe2 Di Indonesia 2015 [Internet]. Perkeni. 2015. 82 p. Available from: https://www.google.com/url?sa=t\&source =web\&rct=j\&url=https: $/ /$ pbperkeni.or.id $/ \mathrm{w}$ p-content/uploads/2019/01/4.-

Konsensus-Pengelolaan-dan-

Pencegahan-Diabetes-melitus-tipe-2-diIndonesia-PERKENI-

2015. pdf\&ved=2ahUKEwjy8KOs8cfoAhX Cb30KHQb1Ck0QFjADegQIBhAB\&usg= AOvVaw1PxTUAnZLMkJYCkfCBY1mU

2. Khairani. Hari Diabetes Sedunia Tahun 2018. Pus Data dan Inf Kementrian Kesehat RI. 2019;1-8.

3. International Diabetes Federation. Diabetes Atlas Sixth Edition. Idf Diabetes Atlas. 2013.

4. Donelly rudy bilous dan richard. pendahuluan tentang diabetes. In: Buku Pegangan Diabetes. 2014.

5. Hastuti RT. Pada Penderita Diabetes Mellitus (Studi Kasus di RSUD Dr. Moewardi Surakarta) Tesis Untuk memenuhi sebagian persyaratan Mencapai Derajat Sarjana S-2 Magister Epidemiologi. Tesis. 2008;

6. Sri E, Ningsih P, Ui F. Endang Sri $P$ Ningsih Program Pascasarjana Fakultas IImu Keperawatan Kekhususan Keperawatan Medikal Bedah Universitas Indonesia Depok 2008. Fak IImu Kesehatan. 2008;30-45.

7. Sofiana LI, Elita V, Utomo W. Hubungan 
antara stress dengan konsep diri pada penderita DM 2. J Ners Indones. 2012;2(2):167-76.

8. Rantung J, Yetti K, Herawati T. Hubungan Self-Care Dengan Kualitas Hidup Pasien Diabetes Mellitus (Dm) Di Persatuan Diabetes Indonesia (Persadia) Cabang Cimahi. J Sk Keperawatan. 2015;1(01):38-51.

9. Wilkinson, J.M. Diagnosis Keperawatan. 2017.

10. Putri LR. Gambaran Self Care Penderita Diabetes Melitus (DM) di Wilayah Kerja Puskesmas Srondol Semarang. Skripsi [Internet]. 2017;(Dm):1-180. Available from:

http://eprints.undip.ac.id/59801/1/SKRIP SI_LINDA_RIANA_PUTRI.pdf

11. Setyaningrum I. Studi Eksplorasi Kualitas Hidup Pasien Dengan Diabetes Melitus Tipe 2 Di Puskesmas Program Studi S-1 Keperawatan Stikes Kusuma Husada. 2016;

12. Aalaa M, Malazy OT, Sanjari M, Peimani $M$, Mohajeri-Tehrani MR. Nurses' role in diabetic foot prevention and care; a review. J Diabetes Metab Disord. 2012;11(1).

13. Sasa. Diabetes Melitus Tipe 2. Fak Kedokt Univ Lampung. 2016;4:500.

14. Drecoli, E, Diabetes Mellitus Tipe 2.2019

15. Heather $\mathrm{TH}$. Diagnosis Keperawatan Definisi \& Klasifikasi 2015-2017. In: NANDA-I Diagnosa Keperawatan Definisi dan Klasifikasi. 2018.

16. Lindarto $D,$. Hubungan Diabetes Dengan Disfungsi Ereksi.Availsble from: www.yankes.kemkes.go.id.2018 